\title{
Non-enzymatic Glycosylation of Tissue Protein in Diabetes in the Rat
}

\author{
D. K. Yue, S. McLennan and J. R. Turtle \\ Department of Medicine, Lniversity of Sydney, Department of Endocrinology, Royal Prince Alfred Hospital, Sydney, \\ New South Wales, Australia
}

\begin{abstract}
Summary. Non-enzymatic glycosylation of tissue and haemolysate proteins has been studied in normal and diabetic rats by reduction with tritiated sodium borohydride $\left(\mathrm{NaB}^{3} \mathrm{H}_{4}\right)$ alone or in combination with chromatography on $\mathrm{m}$-aminophenylboronic acid coupled to Biogel P-6. With $\mathrm{NaB}^{3} \mathrm{H}_{4}$ reduction alone, there was a linear relationship between plasma glucose and tritium incorporation into haemolysate protein. However, increased non-enzymatic glycosylation of tissue protein could not be demonstrated with $\mathrm{NaB}^{3} \mathrm{H}_{4}$ reduction alone. Tritiated glycosylated amino acids could be selectively removed by $\mathrm{m}$ -
\end{abstract}

aminophenylboronic acid immobilized on Biogel P-6, then eluted by acidification and the radioactivity in the acidic peak used to estimate non-enzymatic glycosylation. Using the combined techniques, an increase in non-enzymatic glycosylation was observed in heart, kidney and liver obtained from rats with diabetes of 18 weeks duration.

Key words: Non-enzymatic glycosylation, diabetes, glycosylated haemoglobin, complications, rat
An increase in non-enzymatic glycosylation of haemoglobin and plasma proteins in diabetes has been well established and the phenomenon is used in the assessment of diabetic control [1-5]. It has been suggested that increased glycosylation of tissue proteins in diabetes may take place and this could be of importance in the pathogenesis of long-term diabetic complications [6, 7]. Increased glycosylation of lens, red cell membrane, nerve, glomerular basement membrane proteins and aorta have been reported [8-12], but there has been no systematic study of glycosylation in other tissues. It would be of interest to compare the extent of non-enzymatic glycosylation in a variety of tissues, including those not normally affected by diabetic complications. This may provide valuable information as to the physiological significance of non-enzymatic glycosylation.

The measurement of tissue protein glycosylation is more difficult than that of glycosylated haemoglobin or plasma proteins. In this study the technique of tritiated sodium borohydride $\left(\mathrm{NaB}^{3} \mathrm{H}_{4}\right)$ reduction alone and in combination with $\mathrm{m}$-aminophenylboronic acid chromatography was used to examine non-enzymatic glycosylation of tissues obtained from rats with diabetes of 18 weeks duration. Tritium from $\mathrm{NaB}^{3} \mathrm{H}_{4}$ is incorporated into the ketoamine group of the 1-deoxyfructosyl residue formed by the attachment of glucose to protein $[13,14]$. The resultant tritiated glycosylated amino acids contain dihydroxyl groups in the coplanar cis-diol configuration and in alkaline conditions can be extracted by $\mathrm{m}$-aminophenylboronic acid immobilized on a solid phase [15]. The tritiated glycosylated amino-acids are eluted by acidification and radioactivity in the acidic fraction is an index of non-enzymatic glycosylation. This procedure had been used previously for the measurement of non-enzymatic glycosylation of nerve protein, low-density lipoprotein and glycosylated aminoacids in the urine of diabetic patients $[9,15,16]$.

\section{Materials and Methods}

\section{Induction of Diabetes and Preparation of Tissues}

Inbred female Wistar rats were obtained from the Australian Atomic Energy Commission, Lucas Hcights, NSW. The animals weighed $230 \pm 5 \mathrm{~g}$, and were aged 23 months at the beginning of the experiment. Diabetes was induced with streptozotocin $(65 \mathrm{mg} / \mathrm{kg})$ by IV injection in sodium phosphate buffer $1(50 \mathrm{mmol} / 1, \mathrm{pH} 7.0)$ and confirmed by the presence of tail blood glucose levels $>22 \mathrm{mmol} / 1$ (Ames Glucometer, Elkhart, Indiana, LS $\Lambda$ ) one weck after injection. $A$ group of 16 littermates was studied, of which nine were diabetic and seven served as controls. Animals were killed with Halothane 18 weeks after induction of diabetes and as much blood as possible $(5-10 \mathrm{ml})$ was obtained by cardiac puncture. Plasma glucose levels measured by a Beckman glucose analyser (glucose oxidase method) in diabetic and normal animals were $33.2 \pm 0.6$ and $8.7 \pm 0.2 \mathrm{mmol} / \mathrm{l}$, respectively. Kidncys, liver and heart were removed rapidly, washed 
in $0.15 \mathrm{~mol} / 1$ saline, frozen in liquid nitrogen and stored at $-80^{\circ} \mathrm{C}$. Immediately before study the tissues were thawed, minced finely with a scalpel and homogenized in five volumes of phosphate buffer $_{1}$, using a hand-held Teflon glass homogenizer ( 20 strokes for heart; 10-15 strokes for other tissues). The haemoglobin concentrations in the homogenates were measured by the method of Dodge et al. [17] and found to be $<0.2 \%$ of total protein present. Haemolysate was prepared according to the method of Dodge et al. [17]. Protein concentration was measured by a fluorometric assay using Fluram (Roche, Switzerland) with bovine serum albumin as standard [18]. Protein concentration was adjusted with phosphate buffer $_{1}$ to $20 \mathrm{mg} / \mathrm{ml}$ for the haemolysate and other tissues.

\section{Reduction by $\mathrm{NaB}^{3} \mathrm{H}_{4}$}

$\mathrm{NaB}^{3} \mathrm{H}_{4}$ (specific activity $228-468 \mathrm{mCi} / \mathrm{mmol}$ ) was purchased from Amersham International, Amersham, Bucks, UK. Reduction was commenced by adding $200 \mu 1(2 \mathrm{mCi})$ of $\mathrm{NaB}^{3} \mathrm{H}_{4}$ in phosphate buffer to $1 \mathrm{ml}$ of test material solution (tissue or haemolysate). The total radioactivity was estimated by immediately counting $0.5 \mu \mathrm{l}$ aliquots of reaction mixtures in $10 \mathrm{ml}$ of phase combining system II liquid scintillation mixture in a Wallac-LKB beta liquid scintillation counter (LKB - Produkter, Bromma, Sweden). The reaction was allowed to proceed at room temperature for $40 \mathrm{~min}$ and terminated by cooling in an ice bath. The product was dialysed against phosphate buffer $_{1}(5 \mathrm{l})$, with four changes over $24 \mathrm{~h}$; a procedure shown to remove completely $\mathrm{NaB}^{3} \mathrm{H}_{4}$ and free glucose. Aliquots $(5$ ul $)$ were added to scintillant and counted. Results were expressed as radioactivity (DPM) incorporated per mg of protein. Control experiments showed that ${ }^{3} \mathrm{H}$ incorporation was proportional to the amount of tissue protein $(5-50 \mathrm{mg} / \mathrm{ml})$ present in the incubation mixture. Addition of $\mathrm{NaBH}_{4}$ to a concentration of $25 \mathrm{mmol} / \mathrm{l}$ did not affect the extent of radioactivity incorporated.

\section{Combined $\mathrm{NaB}^{3} \mathrm{H}_{4}$ Reduction and m-Aminophenylboronic Acid Chromatography}

After $\mathrm{NaB}^{3} \mathrm{H}_{4}$ reduction and dialysis, $0.8 \mathrm{ml}$ of treated protein was hydrolyzed in $6 \mathrm{~mol} / 1 \mathrm{HC} 1$ for $16 \mathrm{~h}$ at $108^{\circ} \mathrm{C}$. The hydrolysate was adjusted to $\mathrm{pH} 9.0$ with $7 \mathrm{~mol} / 1 \mathrm{NaOH}$ and the amino acid concentration measured by Fluram using L-leucine as standard.

$\mathrm{m}$-Aminophenylboronic acid immobilized on Biogel P-6 (Affi-Gel 601) was purchased from Bio-Rad Laboratories, Richmond, California, USA and swollen in sodium phosphate buffer $_{2}(50 \mathrm{mmol} / \mathrm{l}$, $\mathrm{pH} 9.0$ ). The gel was packed into a $2.0 \times 1.0 \mathrm{~cm}$ column and equilibrated with $10 \mathrm{ml}$ of phosphate buffer $_{2}$. Tritiated amino-acids obtained by $\mathrm{NaB}^{3} \mathrm{H}_{4}$ reduction and acid hydrolysis of tissues or haemolysate (20 mg amino-acid) were applied to the column, washed with $10 \mathrm{ml}$ of phosphate buffer ${ }_{2}$ and collected in one fraction. The eluting fluid was then changed to $10 \mathrm{ml}$ of $0.25 \mathrm{~mol} / 1 \mathrm{HC} 1$ and collected. Radioactivity in each fraction was monitored by counting $200 \mu \mathrm{l}$ in $10 \mathrm{ml}$ of phase combining system II liquid scintillation fluid. Radioactivity recovered in the acidic (second) peak is an estimate of non-enzymatic glycosylation. Results were expressed as radioactivity in the acidic peak per mg of amino-acid applied to the column.

Three diabetic and three normal rats were studied by the combined technique of $\mathrm{NaB}^{3} \mathrm{H}_{4}$ reduction and m-aminophenylboronic acid chromatography. These rats were selected randomly from the group of 16 previously studied by $\mathrm{NaB}^{3} \mathrm{H}_{4}$ reduction alone. The blood glucose and body weight of these rats were not significantly different from other animals in the experimental group.

To test for the effects of lipid on measurement of non-enzymatic glycosylation, all samples of $\mathrm{NaB}^{3} \mathrm{H}_{4}$-reduced tissue hydrolysates were subjected to chloroform-methanol extraction. Aliquots $(1 \mathrm{ml})$ of the acid hydrolysates were mixed with $2 \mathrm{ml}$ of triple distilled chloroform and $1 \mathrm{ml}$ of methanol and allowed to stand overnight. Aliquots $(50 \mu \mathrm{l})$ of the chloroform phase and of the methanol phase were counted in $10 \mathrm{ml}$ of phase combining system Il scintillation fluid to determine the proportion of counts incorporated into lipid during the $\mathrm{NaB}^{3} \mathrm{H}_{4}$ reduction. The remainder of the methanol phase was lyophi- lized, reconstituted in $500 \mu \mathrm{l}$ of phosphate buffer $_{2}$ and used in maminophenylboronic acid chromatography.

The effect of free glucose or haemoglobin in the vasculature on measurement of non-enzymatic glycosylation was assessed by the following experiments. Rats were anaesthetized with Ketamine (ParkeDavies, Caringbah, NSW, Australia) $(140 \mathrm{mg} / \mathrm{kg}$ body weight) and laparotomy performed via a median incision. Right nephrectomy was performed and a catheter inserted into the aorta and placed just above the origin of the left renal artery. The left kidney was perfused in a non-recirculating system with $200 \mathrm{ml}$ of cold $\left(4^{\circ} \mathrm{C}\right)$ saline $(0.15 \mathrm{~mol} / \mathrm{l})$ with or without glucose $(25 \mathrm{mmol} / \mathrm{l})$. After perfusion the left kidney was excised and processed as described previously for $\mathrm{NaB}^{3} \mathrm{H}_{4}$ reduction and m-aminophenylboronic acid chromatography. The right kidney of each animal was used as a control. In total, two diabetic and three normal rats were studied in this manner. In addition non-enzymatic glycosylation was measured in two kidney homogenates (one normal and one diabetic) which had been dialyzed for $24 \mathrm{~h}$ and also in two other normal kidney homogenates augmented with glucose to reach a final concentration of 12.5 and $25 \mathrm{mmol} / \mathrm{l}$. In each case the left kidney was treated and the right kidney served as a control.

\section{Preparation of Glycosylated Lysine and Identification of the Acidic Peak}

Poly-L-lysine (mol. wt. 60,000) was purchased from Sigma, St.Louis, Missouri, USA. Glycosylation was carried out by incubating $50 \mathrm{mg}$ of the protein at $37^{\circ} \mathrm{C}$ for 10 days in phosphate buffer $_{1}$ containing $25 \mathrm{mmol} / 1$ of glucose. Sodium azide $(1 \mathrm{mmol} / \mathrm{l})$ was added to prevent infection. A control sample was incubated in phosphate buffer ${ }_{1}$ alone under identical conditions. After incubation the free glucose was removed by dialysis against 51 of phosphate buffer $_{1}$ (four changes in $24 \mathrm{~h}$ ). The remaining glycosylated and non-glycosylated poly-L-lysine was treated with $\mathrm{NaB}^{3} \mathrm{H}_{4}(20 \mathrm{mCi})$, dialysed and subjected to acid hydrolysis as described previously. Tritiated hydrolysate thus obtained (20 mg amino-acid) was applied to a m-aminophenylboronic acid column and eluted as before. The acidic peak obtained from chromatography of glycosylated lysine was used as reference standard.

The acidic peaks obtained from glycosylated poly-L-lysine, diabetic and normal tissues were studied by high pressure liquid chromatography using a Waters Associate Machine with a micro- $\mathrm{NH}_{2}$ Bondapak column (Waters Associate, Sydney, Australia). Elution was carried out in a step-wise manner using acetonitrile-phosphate gradient [19]. Elution positions of several radioactive amino-acids were also determined. The same samples were also studied on a Beckman $121 \mathrm{M}$ amino-acid analyser using Beckman AA-15 resin packed in a column of $4.5 \times 0.28 \mathrm{~cm}$. Amino-acids were eluted by sodium citrate buffer $(0.35 \mathrm{~mol} / 1, \mathrm{pH} 5.26)$ at $51^{\circ} \mathrm{C}$ and collected in $1 \mathrm{ml}$ fractions.

\section{Statistical Method}

Results were expressed as mean \pm SEM. Linear regression was calculated by the least squares method.

\section{Results}

\section{$\mathrm{NaB}^{3} \mathrm{H}_{4}$ Reduction}

Tritium incorporation into haemolysate protein was two- to threefold higher in diabetic animals. There was a good correlation between the incorporation of tritium and plasma glucose levels at the time of sacrifice $(r=0.77, p<0.002)$. Tritium incorporation into glycosylated poly-L-lysine $\left(6 \times 10^{6} \mathrm{DPM} / \mathrm{mg}\right)$ was also increased in comparison with non-glycosylated poly-L-ly- 
Table 1. Tritium incorporation into protein during $\mathrm{NaB}^{3} \mathrm{H}_{4}$ reduction

\begin{tabular}{lll}
\hline Tissue & $\begin{array}{l}\text { Normal rats }(n=7) \\
\left(\mathrm{DPM} \times 10^{-5} / \mathrm{mg}\right. \\
\text { protein) }\end{array}$ & $\begin{array}{l}\text { Diabetic rats }(n=9) \\
\left(\mathrm{DPM} \times 10^{-5} / \mathrm{mg}\right. \\
\text { protein) }\end{array}$ \\
\hline Heart & $2.53 \pm 0.06$ & $2.45 \pm 0.05$ \\
Kidney & $4.00 \pm 0.07$ & $4.60 \pm 0.10$ \\
Liver & $2.30 \pm 0.04$ & $2.30 \pm 0.05$ \\
\hline
\end{tabular}

Results expressed as mean \pm SEM

Table 2. Radioactivity in acidic peaks after m-aminophenylboronic acid chromatography of acid hydrolysate

\begin{tabular}{lll}
\hline Tissue & $\begin{array}{l}\text { Normal rats }(n=3) \\
\left(\mathrm{DPM} \times 10^{-3} / \mathrm{mg}\right. \\
\text { amino acid) }\end{array}$ & $\begin{array}{l}\text { Diabetic rats }(n=3) \\
\left(\mathrm{DPM} \times 10^{-3} / \mathrm{mg}\right. \\
\text { amino acid) }\end{array}$ \\
\hline Haemolysate & $3.3 \pm 1.8$ & $20.3 \pm 8.9$ \\
Kidney & $2.7 \pm 1.6$ & $6.1 \pm 1.9$ \\
Liver & $3.4 \pm 0.1$ & $4.4 \pm 0.4$ \\
Heart & $1.9 \pm 0.7$ & $5.8 \pm 1.5$ \\
\hline
\end{tabular}

Results expressed as mean \pm SEM

sine $\left(3 \times 10^{5} \mathrm{DPM} / \mathrm{mg}\right)$. However, when $\mathrm{NaB}^{3} \mathrm{H}_{4}$ reduction alone was used to study non-enzymatic glycosylation of kidney, liver and heart, no difference in the incorporation of tritium could be demonstrated between normal and diabetic tissues (Table 1). In general, the percentage of tritium incorporated was rather small, reaching only $0.4 \% / \mathrm{mg}$ protein in kidney.

\section{$\mathrm{NaB}^{3} \mathrm{H}_{4}$ Reduction and m-Aminophenylboronic Acid Chromatography}

Chromatography of glycosylated and non-glycosylated lysine showed that $>85 \%$ of tritiated glycosylated lysine was retained by the m-aminophenylboronic acid column and could be eluted by acidification, whereas only $5 \%$ of the tritiated non-glycosylated lysine was retained. In all samples studied a large peak of radioactivity could be eluted with phosphate buffer ${ }_{2}$ but only a relatively small fraction of the radioactivity was retained by the column and eluted following acidification. Total radioactivity recovered (alkaline peak + acidic peak) was $96.9 \pm 2.7 \%$ for all samples. The acidic peak contained tritiated glycosylated amino-acids and when expressed as radioactivity/mg of amino acid applied to column it was higher in all diabetic tissues or haemolysates studied (Table 2).

\section{Identification of Radioactivity in the Acidic Peak}

When the acidic peaks of hydrolysates from all diabetic and normal tissues were studied by either high pressure liquid chromatography or amino-acid column chroma-

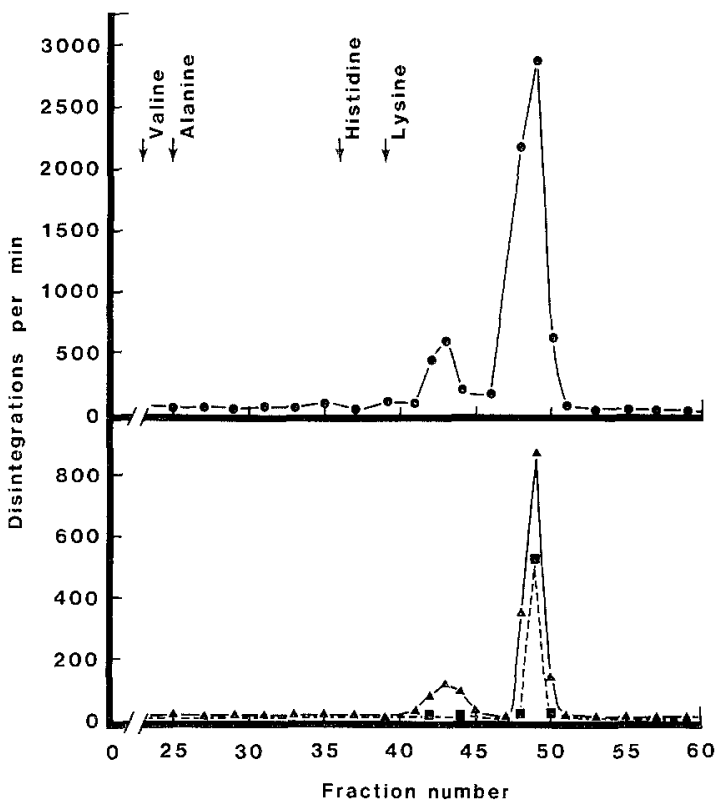

Fig. 1. High pressure liquid chromatography pattern of acidic peaks obtained from m-aminophenylboronic acid chromatography. Top panel: glycosylated lysine $\longrightarrow$. Bottom panel: diabetic kidney -A normal kidney Each fraction is $1.0 \mathrm{ml}$ in volume. Elution positions of various tritiated amino acids are indicated by arrows

tography; they were eluted in the same position as glycosylated lysine. Typical elution patterns on high pressure liquid chromatography are shown in Figure 1.

\section{Chloroform-Methanol Extraction Experiments}

In all samples of acid hydrolysate subjected to chloroform-methanol extraction $<1 \%$ of radioactivity was recovered in the chloroform phase and there was no difference between the diabetic and normal samples. When tritium-labelled amino acids in the methanol phase were applied to the m-aminophenylboronic acid column, a higher amount of radioactivity was recovered in the acidic peak of diabetic samples.

\section{Perfusion and Dialysis Experiments}

The radioactivity in the acidic peak was reduced by $10 \%$ when the left kidney was perfused before measurement of non-enzymatic glycosylation. This reduction occurred in both normal and diabetic kidney and was not affected by addition of glucose $(25 \mathrm{mmol} / \mathrm{l})$ to the perfusate. Similar reduction could be observed if diabetic or normal kidney homogenate was dialysed for $24 \mathrm{~h}$ before $\mathrm{NaB}^{3} \mathrm{H}_{4}$ treatment. However, even after perfusion or dialysis, the radioactivity recovered in the acidic peak of diabetic kidneys was two- to threefold higher than that obtained from normal kidney. In agreement with the perfusion experiments, addition of glucose to kidney homogenates to reach a final concentration of 12.5 or $25 \mathrm{mmol} / 1$ had no effect on the recovery of radioactivity in the acidic peak. 


\section{Discussion}

The measurement of glycosylated haemoglobin or glycosylated plasma proteins is now generally available for the assessment of metabolic control in diabetes [3-5]. It has been suggested that the process of non-enzymatic glycosylation of protein is a more generalized phenomenon affecting body tissues as well as circulating proteins $[6,7,16]$. Investigations in this important area have been limited by the technical difficulty of measuring tissue glycosylation [15]. The popular method of $\mathrm{NaB}^{3} \mathrm{H}_{4}$ reduction is not specific for the ketoamine bond of the glycosylation adduct. Depending on the conditions of the reduction, fatty acid ester can be reduced to its alcohol and peptide bonds can be converted to amino alcohols $[20,21]$. Thus, in the case of tissue proteins it was necessary to extract selectively only those residues with tritium specifically bound to the ketoamine bond of the non-enzymatic glycosylation reaction. This was achieved using a combination of $\mathrm{NaB}^{3} \mathrm{H}_{4}$ reduction and $\mathrm{m}$-aminophenylboronic acid chromatography. This technique had been used by Brownlee et al. to study levels of glycosylated peptides and amino acids in urine and peripheral nerves $[9,22]$ and by Witztum et al. [16] to study glycosylation of low density lipoprotein.

m-Aminophenylboronic acid reacts in alkaline conditions with residues possessing hydroxyl groups in the coplanar cis-diol configuration and will thus selectively remove glycosylated amino acids from other substances present in the incubation mixture. The immobilized tritiated glycosylated amino acids are recovered and quantitated after acidification. The m-aminophenylboronic acid column also immobilizes free glucose, ATP and ribonucleic acid [23, 24]. However these substances are either removed by the prior extensive dialysis of the samples or not reduced by $\mathrm{NaB}^{3} \mathrm{H}_{4}$, thus they do not interfere with the estimation. Amino acids glycosylated by enzymatic mechanisms are also not reducible by $\mathrm{NaB}^{3} \mathrm{H}_{4}$ and would not interfere in this study.

Using the combined technique of $\mathrm{NaB}^{3} \mathrm{H}_{4}$ reduction and m-aminophenylboronic acid chromatography a consistent increase in non-enzymatic glycosylation was demonstrated in diabetic tissues when measured in terms of radioactivity present in the second peak. The finding of similar results in the chloroform-methanol treated samples ruled out the possibility that interference by lipid was responsible for the observed increase. As $\mathrm{NaB}^{3} \mathrm{H}_{4}$ was used only in tracer quantity in this study the increase in non-enzymatic glycosylation could not be reported in absolute molar terms. The difference of diabetic and normal tissues was not abolished by perfusion or dialysis of the samples before $\mathrm{NaB}^{3} \mathrm{H}_{4}$ reduction and could not be mimicked by addition of glucose to normal kidney. Thus, it is unlikely that free glucose or haemoglobin in the vasculature can account for the results observed. In accord with the findings of Brownlee et al. [15], and Witztum et al. [16] we also found non- enzymatic glycosylation to occur by attachment to lysine.

The significance of increased tissue non-enzymatic glycosylation in diabetes remains to be resolved. Glycosylation of haemoglobin has been shown to increase its oxygen affinity and may be important in causing tissue hypoxia and diabetic complications [25]. Increased glycosylation of red cell membrane may be important in causing changes in viscosity of the red cell membrane known to exist in diabetes [26]. The significance of nonenzymatic glycosylation on the stability of collagen fibres was studied previously $[27,28]$. Increased non-enzymatic glycosylation of low density lipoprotein may be important in the metabolism of this protein and in atherosclerosis [16]. Our preliminary observation that tissue glycosylation was increased in most tissues would suggest that glycosylation is a general phenomenon. The smaller increase of non-enzymatic glycosylation of liver may account for the relative sparing of this organ from diabetic complications. It is possible that a selective increase in glycosylation of some tissue components may be more important in changing the functional properties of proteins. Further studies need to be carried out to investigate the dynamics of tissue glycosylation, the reversibility by insulin therapy and to identify functional changes in proteins induced by tissue glycosylation.

Acknowledgement. This study was supported by the Coppleson Postgraduate Medical Institute of NSW, the John Claude Kellion Foundation, and the National Health and Medical Research Council of Australia. We thank Professor E. Thompson and Mr. R. Mann for performing the amino-acid chromatography.

\section{References}

1. Bunn FH, Gabbay KH, Gallop PM (1978) The glycosylation of haemoglobin: relevance to diabetes mellitus. Science 200: 21-27

2. Bookchin RM, Gallop PM (1968) Structure of haemoglobin $A_{1 c}$ : Nature of the N-terminal chain blocking group. Biochem Biophys Res Commun 32:86-93

3. Yue DK, Morris K, McLennan S, Turtle JR (1980) Glycosylation of plasma protein and its relation to glycosylated haemoglobin in diabetes. Diabetes 29: 296-300

4. Day JF, Thorpe SR, Baynes JW (1979) Non-enzymatically glycosylated albumin. J Biol Chem 254: 595-597

5. Koenig RJ, Peterson CM, Jones RL, Saudek C, Lehrman M, Cerami A (1976) Correlation of glucose regulation and hemoglobin $A_{1 c}$ in diabetes mellitus. N Engl J Med 295: 417-420

6. Cerami A, Stevens VJ, Monnier VM (1979) Role of non-enzymatic glycosylation in the development of the sequelae of diabetes mellitus. Metabolism 28: 431-437

7. Bunn HF (1981) Non-enzymatic glycosylation of protein: relevance to diabetes. Am J of Med 70:325-330

8. Stevens VJ, Rouzer CA, Monnier VM, Cerami A (1978) Diabetic cataract formation: potential role of glycosylation of lens crystallins. Proc Natl Acad Sci USA 75: 2918-2922

9. Vlassara H, Brownlee M, Cerami A (1981) Non-enzymatic glycosylation of peripheral nerve protein in diabetes mellitus. Proc Natl Acad Sci USA 78: 5190-5192

10. Miller JA, Gravalles E, Bunn HF (1980) Non-enzymatic glycosylation of erythrocyte membrane proteins. J Clin Invest 65: 896-901

11. Cohen MP, Urdanivia E, Surma M, Ciborowski J (1981) Non-en- 
zymatic glycosylation of basement membranes. Diabetes 30 : $367-371$

12. Rosenberg H, Modrak JB, Hassing JM, Al-Turk WA, Stohs SJ (1979) Glycosylated collagen. Biochem Biophys Res Commun 91: 498-501

13. Bunn HF, Shapiro R, McManus M, Garrick L, McDonald J, Gallop PM, Gabbay KH (1979) Structural heterogeneity of human haemoglobin A due to non-enzymatic glycosylation. J Biol Chem 254: 3892-3898

14. Pande A, Garner WH, Spector A (1979) Glycosylation of human lens protein and cataractogenesis. Biochem Biophys Res Commun 89: 1260-1266

15. Brownlee M, Vlassara H, Cerami A (1980) Measurement of glycosylated amino acids and peptides from urine of diabetic patients using affinity chromatography. Diabetes 29 : 1044-1047

16. Witztum JL, Mahoney EM, Branks MJ, Fisher M, Elam R, Steinberg D (1982) Non-enzymatic glycosylation of low-density lipoprotein alters its biological activity. Diabetes 31: 283-291

17. Dodge JT, Mitchell C, Hanahan DJ (1963) The preparation and chemical characteristics of haemoglobin-free ghosts of human erythrocytes. Arch Biochem Biophys 100: 119-130

18. Udenfriend S, Stein S, Bohlen P, Dairman W (1972) Fluorescamine: a reagent for assay of amino acids, proteins, and primary amines in the picomole range. Science 178: $871-872$

19. Schuster R (1980) Determination of free amino acids by high performance liquid chromatography. Anal Chem 52: 617-620

20. Nichols BW, Safford R (1973) Conversion of lipids to fatty alcohols and lysolipids by $\mathrm{NaBH}_{4}$. Chem Phys Lipids 11: 222-227

21. Paz MA, Henson E, Rombauer R, Abrash L, Blumenfeld OO, Gallop PM (1970) $\alpha$-amino alcohols as products of a reductive side reaction of denatured collagen with sodium borohydride. Biochemistry 9:2123-2127
22. Vlassara H, Brownlee M, Cerami A (1981) Non-enzymatic glycosylation of peripheral nerve protein in diabetes mellitus. Diabetes 30 (Suppl 1): Abstract 119

23. Ferrier RJ (1978) Carbohydrate boronates. Adv Carbohydr Chem Biochem 35: 31-30

24. Schott H, Rudloff E, Schmidt P, Roychoudhury R, Kossel H (1973) A dihydroxyboryl-substituted methacrylic polymer for the column chromatographic separation of mononucleotides, oligonucleotides, and transfer ribonucleic acid. Biochemistry 12: 932-938

25. Ditzel J (1976) Oxygen transport in diabetes. Diabetes 25 (Suppl 2): 832-838

26. McMillan DE, Utterback NG, La Puma J (1978) Reduced erythrocyte deformability in diabetes. Diabetes 27: 895-901

27. Robins SP, Bailey AJ (1972) Age-related changes in collagen: The identification of reducible lysine-carbohydrate condensation products. Biochem Biophys Res Commun 48: 76-83

28. Yue DK, McLennan S, Delbridge L, Handelsman DJ, Reeve T, Turtle JR (1982) The thermal stability of collagen in diabetic rats: correlation with severity of diabetes and non-enzymatic glycosylation. Diabetologia 24: 282-285

Received: 16 August 1982

and in revised form: 6 December 1982

Dr. D. K. Yue

Department of Medicine

University of Sydney

Sydney

NSW 2006

Australia 